\title{
Violencia, ritual y división simbólica de los sexos en Almadén (Ciudad Real)
}

\section{EL ORDEN RITUAL}

Almadén es un pueblo minero del Valle de Alcudia, al este de la región de Sierra Morena. En la actualidad debe contar con unos once mil habitantes, que eran algo menos en los años treinta, período en que me centraré aquí de manera preferente. La mayor parte de la población activa estuvo, desde siempre, dedicada a las tareas derivadas de la extracción de azogue y la elaboración del mercurio, y, el resto, a un restringido cultivo de cereales y del olivo y a la atención de una pequeña cabaña ganadera ${ }^{1}$. Ha conocido la sangría de la emigración y ha visto cómo la crisis amenazaba seguramente de forma irreversible su vieja industria minera. Hoy se habla de Almadén como el lugar de ubicación de una gran planta de tratamiento de residuos tóxicos.

Hay muchas cosas que cambian en el transcurso de más de medio siglo, y, a pesar de ello, el esqueleto de su calendario festivo, con todas las modificaciones y pérdidas que podían preveerse, ha permanecido relativamente estable. Por supuesto, existen celebraciones que han experimentado un proceso de deterioro que ha conducido a su total desaparición. Ese sería el caso de la de San Antón, el 17 de enero, un conjunto ritual centrado en la bendición de animales que tenía como escenario la iglesia de San Juan. Los habitantes de los aledaños de la plaza en que se levanta el templo, instalaban a la puerta de sus casas mesas en las que se distribuían bollos duros que preparaba la popular «abuela Chinda». Teóricamente destinados a los burros, eran disfrutados por la gente como un singular manjar ${ }^{2}$. El inicio del calendario ritual lo señalaba, sin embargo, la festividad de San Sebastián, el 20 de enero, único día del año en que se abría la ermita del mismo nombre, muy cerca de la mina. También aquí la tradición ordenaba que los vecinos

1 La estructura social de Almadén se corresponde con bastante precisión con la reflejada por F. LÓPEZ CASERO, «La plaza. Estructuras y procesos sociales en un pueblo manchego», Ethnica, 4 (1972), pp. 89-136.

2 La festividad de San Antón estaba muy extendida - y todavía lo está- en toda la zona manchega. Descripciones de varios ejemplos los podemos encontrar en $\mathrm{N}$. de Hoyos Sancho, Las fiestas de San Antón (Madrid: Publicaciones Españolas, 1958), (col. Temas Españoles, 299). 
de la zona, la llamada Los Carriles, sacaran a la calle sus mesas para invitar a los feligreses que acudían al culto. Eran estos dos, San Antón y San Sebastián, los llamados «santos viejos», una designación que en otros lugares manchegos también sirve para delimitar el ciclo festivo de invierno ${ }^{3}$, y que en algunos empareja a estos dos personajes para crear en torno suyo una interesante organización de cofradía, como ocurre en Moratilla de los Meleros, Pastrana o Budia ${ }^{4}$. El siguiente episodio destacado era, como corresponde a la zona cultural manchega, el Carnaval, hoy heterosexual, pero entonces exclusivamente masculino.

Se llegaba así a la Semana Santa, quizá el centro neurálgico de toda la puntación festiva, con que los almadenenses hacían mentalmente habitable el tiempo social. El Jueves y el Viernes Santo se sacaban en procesión desde la iglesia principal del pueblo, la de Jesús, las imágenes del Nazareno, de San Sebastián, que hacía las veces de Señor en la Columna, de la Dolorosa... Era extraordinariamente popular la del Entierro. La celebración que más implicaba la participación masiva de los lugareños era, sin embargo, la del Domingo de Resurrección. Ese día todo el mundo sin excepción se iba al campo, a las Casas del Vivero o a la era del Barbudillo, a comer cordero y a mantear el Judas, ese pelele de trágico destino que es agredido ceremonialmente una vez al año, en multitud de comunidades de la región por Pascua, aunque aparezca también en muchos lugares en la fase carnavalesca del calendario '. El pueblo quedaba, y queda aún hoy en tal jornada, completamente vacío.

Entre las fiestas del ciclo veraniego, destacaba la de la Virgen del Castillo, el 15 de agosto. Se trataba de una advocación de la cercana villa de Chillón, que se rendía en una antigua fortaleza situada en una elevación equidistante entre ésta y Almadén, y que además se constituía en el escenario de ritualización de la rivalidad que siempre habían mantenido estas dos poblaciones. A pesar de ser chillonera, la Virgen tenía en su fiesta una romería que partía de Almadén y que se reunía en la

3 Por ejemplo, en Almagro. Cf. F. Asensio Rubio, «Las fiestas populares de Almagro: los 'Santos Viejos'», III Jornadas de Etnología de Castilla-La Mancha, Guadalajara, 1985 (Toledo: Junta de Comunidades de Castilla-La Mancha, 1987), pp. 76-91. Para una visión general de las festividades manchegas, me remito a $\mathrm{N}$. de HoYOS SANCHO, «Fiestas patronales y principales devociones de la Mancha», RDTP, III (1947), pp. 113-44.

+ Cf. E. NavarRete, «Devociones típicas: las Hermandades de San Antón y San Sebastián», RDTP, III (1947), pp. 145-50.

Se sostiene que el Judas aparece por Pascua en los lugares donde no hay tradición carnavalera. Cf. GonzÁlez CASARrubios, Fiestas toledanas (Toledo: Junta de Comunidades de Castilla-La Mancha, 1986), p. 56. 
cima con la procedente del pueblo vecino. Por último, y antes de alcanzar los navideños, cabe destacar los festejos que venían a cumplir las veces de patronales, aunque no lo fueran en su sentido estricto, puesto que éstos corresponden oficialmente a finales del mes de julio. Se trataba de honrar a la Virgen de la Mina, patrona de los trabajadores de la extracción del azogue, una imagen que permanecía en su pequeña capilla en el interior de las galerías hasta que era sacada a principios de septiembre para su Novena y venerada en procesión multitudinaria el día 8.

\section{RELIGIOSIDAD Y NOVIAZGO}

Hasta aquí hemos visto el aspecto apreciable en primera instancia de lo que era la dinámica festiva almadenense, en la que reconoceríamos muchos de los tópicos característicos de ese ente conceptual que es la «religiosidad popular», y en relación con el cual parecerían pertinentes todos los lugares comunes de rigor a propósito del papel sociointegrador de la fiesta, la restauración del caos inicial, el reflejo de la estructura comunal, etc. Otra mirada algo más profunda pondría de manifiesto matices y aristas que harían a su vez detectables no sólo ciertas funciones normativizadoras de la esfera festiva, sino también el elevadísimo dintel de tensión que llegan a generar y, a la vez, a resolver, aunque sea tan sólo de una forma provisional y precaria.

La práctica festiva se presentaba fuertemente interesada en intervenir en las relaciones intersexuales de los jóvenes y en los trámites que conducían y aseguraban el noviazgo. Ese interés de la fiesta en articularse con las prácticas convivenciales asociadas al establecimiento de relaciones estratégicas entre muchachos y muchachas aparece por doquier. Repasando el calendario festivo que acabamos de resumir, vemos cómo el espacio religioso, ya de por sí cargado de exaltaciones afectuosistas, muchas veces equívocas, era revestido de un valor esencial en orden a cobijar contactos entre mozos y mozas. Ese es el caso de la procesión de la Virgen de la Mina, en la que la pequeña imagen, que veía la luz en esos días, era llevada en andas por chicos y chicas solteros del pueblo, como si, misteriosamente, su patrocinio sobre la villa y sobre su principal actividad económica tuviera una especial debilidad en privilegiar en el trato ritual con ella a la juventud, no bajo el aspecto díscolo que caracteriza casi siempre su presencia festiva, sino mostrándose ordenada y disciplinadamente. Caso parecido es el de la Romería a la Virgen del Castillo. Se trataba de oportunidades que parecían so- 
cialmente dispuestas para trabar y fortalecer conocimientos personales entre jóvenes de distintos sexos. Es más, muchos de los futuros matrimonios en el pueblo tenían en este momento ritual su punto de partida o un referente importante.

El otro momento esencial de la relación entre el ciclo festivo y las negociaciones prenupciales estaba situado en la Semana Santa. A diferencia de otros lugares de la región en los que el cortejo aparecía asociado a la Pascua " - que aquí tiene un carácter más familiar que intersexual-, en Almadén se producía un curioso desplazamiento que obligaba a los jóvenes a desobedecer frontalmente las normas eclesiales sobre la celebración de los días de la Pasión y seguir, por contra, la sorprendente obligación tradicional de ir a divertirse a un lugar situado en el límite mismo del pueblo, en una franja que servía de frontera entre el casco urbano y los territorios escasamente cultivados que se extendían más allá. Aquel amplio espacio despejado, que por su forma recibía el nombre de El Óvalo, sólo era utilizado prácticamente aquellos días y para aquella función de escenario lúdico, en unas fechas que la Iglesia instaura como de absoluto recogimiento. Allí, la muchachada se entregaba a juegos que con frecuencia actuaban como mecanismos de emparejamiento entre jóvenes de distinto sexo: el cinto, la gallina ciega, los viudos, la barca, etc ${ }^{7}$. Debe decirse que durante el franquismo las autoridades religiosas intentaron restringir la práctica de tan irrespetuosa costumbre, sin, como suele ocurrir en estos casos, conseguirlo.

Y aún más ostensible en su intención era la otra costumbre que seguían los padres de los prometidos de visitar por primera vez la casa de sus futuros consuegros por Semana Santa. La tradición imponía que la noche de Jueves Santo el novio y su familia acudiesen al domicilio de la novia para concertar formalmente el compromiso nupcial, visita que se repetía a la recíproca la noche del siguiente día, esto es la del Viernes Santo. Hay que decir, por lo demás, que la elección de los días, destinados en el calendario litúrgico a la evocación anual de la muerte de Cristo en la cruz, para establecer pactos patrimoniales entre familias, confirmando y solidificando el noviazgo de los hijos, estaba no sólo ampliamente difundida por todo el Valle de Alcudia y La

6 Véase, por ejemplo, R.-J. CAÑADA SOLAZ, «Funcionalidad de las celebraciones de Pascua en el proceso de pre-noviazgo: comarca Requena-Utiel», II Jornadas de Etnología de Castilla-La Mancha. Ciudad Real, 1984 (Toledo: Junta de Comunidades de Castilla-La Mancha, 1985), pp. 259-64.

Cf. A. A. Pozuela Reina, «Catálogo de juegos infantiles en extinción: Ciudad Real, 1.` parte», II Jornadas..., pp. 241-47; y «Catálogo de juegos infantiles en extinción, $2 .^{2}$ y $3 .^{2}$ partes», III Jornadas..., pp. 121-39. 
Mancha en general, al menos hasta la década de los cuarenta ${ }^{8}$, sino en otros lugares de la Península, como en la propia Barcelona, hasta principios de siglo 9. Una costumbre ciertamente inquietante, no sólo por la implicación de la práctica religiosa festiva en las estrategias sociales, destinadas a hacer irreversible el proceso de noviazgo, sino también por la grave sugerencia que supone el asimilar la formalización de la promesa de matrimonio con la evocación de la muerte atroz de un dios joven y viril a manos de su propia comunidad social, porque esa sería la consecuencia de aplicar un principio tan habitual en ritualística como es aquél según el cual, y siguiendo a Mauss, el mito es completamente natural al rito. Mientras el rito es la acción sagrada, el mito es la palabra sagrada que sigue a esa acción o gesto, ilustra la palabra sagrada o el gesto sagrado. Es evidente que la discusión acerca de si es al mito o al rito al que le corresponde la preeminencia hace tiempo que se ha extinguido. Quede como una pista sobre el sentido de esa disolución de lo que en gran medida era un falso problema lo que insinuara Lévi-Strauss acerca de las posibilidades de aplicar en esta cuestión las apreciaciones de la teoría de juegos sobre táctica -el ritoy estrategia - el mito ${ }^{10}$.

Lo que sí debería resultar obvio es que lo que se está insinuando es una equiparación estructural tácita pero inequívoca: la que se puede establecer entre el episodio mítico central, en torno al cual gira cualquier actividad ritualizada en estas fechas santas, que no es otro que el de pasión y muerte de Jesucristo, y el hecho de que una pareja refuerce relaciones formales con la finalidad de casarse, relaciones que a partir de ese momento resultan de improbable reversibilidad. Significa esto que, de alguna forma, se entiende que la acción mítica, en la que el joven dios filial culmina el proceso fatal al que estaba sobrenaturalmente predestinado, es equivalente a una culminación, en este caso parcial, aunque estratégicamente valiosísima, del proceso al que están socialmente predestinados los jóvenes y que es el que conduce al matrimonio y a la integración en el sistema de parentesco con roles de responsabilidad. Dicho de otro modo, existe un planteamiento homologador entre la pasión y el noviazgo, lo que no debería extrañar si se considera el valor pascual, esto es literalmente de paso, que tiene el período de trán-

8 Cf. N. de HOYOS SANCHO, «Costumbres referentes al noviazgo y a la boda en La Mancha», RDTP, IV (1948), pp. 454-69; y C. Villalvilla, "Costumbres de boda en Fuensabiñán (Guadalajara) y en Tornadizo (Avila)», RDTP, XIV (1958), p. 181.

9 Nieves de Hoyos SANCHO, «Noviazgo», RDTP, I (1944-1945), p. 777.

10 Claude LÉvi-Strauss, Palabra dada (Madrid: Espasa Calpe, 1984), pp. 137-41. 
sito entre la soltería y el matrimonio. A partir del dominio dogmático de la Iglesia sobre las actividades relacionadas con lo sagrado, el mitologema de Cristo es el que monopoliza temáticamente y repertorialmente todo el universo simbólico, también el de la cultura popular. Por ello, la pasión de Cristo es el paso paradigmático - una especie de "protopaso»- al que cualquier paso remite, tanto si es sacralizado oficialmente por el sistema teológico dominante - los sacramentos católicos-, como si, al margen de éste, ilustra ritualmente el tránsito entre estados sociales, como sería el caso al que aquí se alude, y, por extensión, el de la casi totalidad de fiestas tradicionales. Además de las presentaciones rituales en los días de la Pasión, habría otras expresiones de ese sistema de equiparaciones, como las canciones y bendiciones del tálamo o como la significativa supervivencia de las teas nupciales hasta no hace mucho en La Mancha, en el momento mismo de la consagración ${ }^{11}$.

En toda esta amalgama de insinuaciones culturales, subyace la idea, suficientemente obvia para darla por sobreentendida en su aplicación por los intervinientes, de que existe un sentido piacular en los distintos ritos, mediante los cuales el novio avanza en sus compromisos hacia el matrimonio y que éste es, de algún modo, sinónimo de la muerte física pasional, lo que justificaría el énfasis en asignar atributos fúnebres a los ritos nupciales, generalmente asimilando la novia a una viuda ${ }^{12}$. Formalmente al menos, se está reconociendo que existe una simetría entre el matrimonio - como acto de muerte-, disolución - reincorporación social- y la muerte de Cristo, y entre el noviazgo y la preparación pasional de aquélla; lo que implícitamente funcionaría como la asignación al mitologema cristiano de un valor insustituible a la hora de referenciar míticamente lo que se considera un destino social ineluctable. Destino, añádase, que está siendo considerado como tan trágico $\mathrm{y}$, en el fondo, tan injusto y arbitrario en su inexorabilidad como aquél que condujera al Salvador a convertirse en un dios asesinado.

Acaso sea pertinente ahora reconstruir las condiciones de cómo se producía en Almadén y durante la primera mitad de siglo el proceso de noviazgo. Me detendré especialmente en la costumbre - vigente hasta no hace tanto- de dividir tripartitamente el período de noviazgo.

1 Cf. V. Rincón, «Costumbres nupciales en Lagartera (Toledo)», RDTP, XIV (1958), pp. 187-192.

12 Piénsese en el caso de la utilización del luto para las novias en Cataluña. Cf. J. Amades, Les esponsalles. Costums i creences (Biblioteca de Tradicions Populars, XXII, 1934), pp. 119-20. 
Se coincidirá en que, en el marco de la sociedad española, el noviazgo constituye una de las principales instituciones de la cultura, de cuyo funcionamiento adecuado depende en gran medida toda la mecánica de integración social de los individuos, al ser eslabón decisivo que los incorpora definitivamente al sistema familiar con roles de responsabilidad. Esto quiere decir que el noviazgo resulta fundamental para el mantenimiento del sistema parentivo y, por tanto, de la organización social en general. Centrado en el control de la vida sexual de los jóvenes, constituye probablemente la fase más delicada de todo el proceso de socialización de los adolescentes y el lugar donde más previsibles resultaban los conflictos, su flanco más vulnerable, por la misma precariedad de la situación estructural de los individuos implicados. Nos encontramos aquí con una muestra de aquéllo que podríamos llamar, a la manera parsoniana, una «zona de tensión». Es esta condición la que genera una intensísima atención cultural, centrada fundamentalmente en hacer que los vínculos establecidos entre los miembros de las nuevas parejas sean cuanto más sólidos mejor, de cara a convertir las situaciones de compromiso intersexual e interfamiliar en no reversibles y dificultando al máximo las tentativas de retroceso.

Sobre las condiciones del noviazgo, en el marco de la ideología sexual de la cultura en general, Pérez Díaz llevó a término una investigación enmarcada en un innombrado pueblo de lo que entonces era Castilla La Nueva ${ }^{13}$, que ha sido confirmada en otras indagaciones posteriores que dan cuenta de su relativa vigencia ${ }^{14}$, y que podría resultar aplicable al caso de Almadén en el período histórico aquí contemplado, y acaso hasta no hace demasiado. Digamos con él que una de las funciones principales de la institución del noviazgo era la de vigilar el cumplimiento de la norma celibal que impedía a los novios tener relaciones sexuales completas precozmente, esto es, antes del matrimonio. La colectividad prestaba gran cuidado en esta cuestión, puesto que se entendía que la virginidad de la novia era, en última instancia, una garantía importante para que la relación culminase en matrimonio. Esta creencia respondía a la opinión de que el mozo deseaba esencialmente tener acceso sexual pleno a su amada y que ese era el gran móvil que le impelía a aceptar el compromiso con la muchacha, de manera que

13 V. PÉrez Díaz, Pueblos y Clases en el campo español (Madrid: Siglo XXI, 1974), pp. 150-77.

14 Cf. P. Díaz Del CAMPO, «Relaciones entre los sexos en una comunidad rural manchega», V Jornadas..., pp. 121-56; o D. GARCía MinguILlÁN, «El noviazgo en Almodóvar del Campo (Ciudad Real)», III Jornadas..., pp. 363-372. 
el noviazgo actuaba en la práctica como una especie de aplazamiento hasta el momento de la noche nupcial. Lo que se concebía era que si la novia, en lo que se entendería como un «momento de debilidad», permitía a su prometido acceder a una relación sexual prematura, éste carecería entonces de alicientes para completar una relación que en el fondo se presumía que aspiraba a «eso», tanto como a constituir una comunidad familiar estable, siempre a partir de una esperada resistencia del hombre joven a establecer relaciones sentimentales estables. Como Pitt-Rivers apreciaba en Grazalema, «el apremio de los hombres en entablar una relación sexual que no tenga importancia estructural contrasta con el cuidado y dilación con el que entran al matrimonio» ${ }^{15}$.

El proceso de formación del imaginario sexual de los jóvenes varones en Almadén respondía al modelo dibujado por Pérez Díaz. Se asignaba un concurso importante a las expectativas sexuales del joven, que habían sido permanentemente estimuladas desde la misma infancia, en el marco familiar, primero a través de la propia madre y luego, en forma de relaciones eróticas menores, con parientes más o menos próximos de ambos sexos ${ }^{16}$. El constante entrenamiento de que había sido objeto y la inculcación en todos los ambientes de una ideología fuertemente «machista» - exaltación de la sexualidad agresiva, ideas de preeminencia del género masculino sobre el femenino, etc.-, que provocaba formas explícitas y exhibidas de sobrevaloración de la propia virilidad, generaban un estado de ánimo determinado, en este campo, por la impaciencia y las exigencias de satisfacción erótica inmediata; exigencias que sólo encontraban relativo alivio en la masturbación, en la ocasional visita a burdeles y en relaciones intrascendentes y, por lo general, frustrantes.

La novia, por su parte, concurría con un papel pasivo en apariencia, consistente en intentar atraer la atención sexual de varones casaderos, poniendo en marcha mecanismos vinculables al concepto de coquetería y seducción femenina, tratando de fascinar a los individuos de otro sexo, provocando sensaciones de excitación, amor pasional luego y que eran experimentadas finalmente bajo la forma sublimada de enamoramiento. La táctica femenina consistía entonces en crear en el varón un máximo de excitación y un mínimo de satisfacciones, provocando sentimientos de exasperación que conducían al joven a un creciente sentimiento de dependencia y un deseo perentorio de controlar el objeto sexual que ha ocasionado la atracción. Para ello, el único mecanismo existente pasaba por aceptar el juego de relaciones propio de la etapa del noviazgo,

15 Julian PITt-Rivers, Un pueblo de la sierra (Madrid: Alianza Ed., 1989), p. 122.

16 Pérez DÍaz, op. cit., pp. 150-2. 
que como mínimo establecería una suerte de garantía de disfrute futuro, siempre y cuando el varón se aviniera al trámite nupcial.

La colectividad, conocedora de que la culturalmente incitada instintividad masculina acabaría abocando al varón a aceptar su integración en la institución del noviazgo, desarrollaba ante la pareja una doble moral sexual, consistente en actuar restrictivamente y, a la vez y de una manera sutil, proporcionar ámbitos de vigilancia menor en los que se favorecería una relación más íntima entre los jóvenes emparejados. Era el caso de las fiestas, bailes, verbenas, carnavales, etc., en los que se esperaba que los varones emprendieran iniciativas en orden a conseguir satisfacciones sexuales con sus novias o amigas íntimas. En estos casos la comunidad sólo podía confiar en que las mozas, de acuerdo con las instrucciones culturales recibidas, no permitieran que los acosos desembocaran en la total consecución de sus objetivos y fueran capaces de desplegar la estrategia del aplazamiento, cosa que no era siempre posible y con respecto a la cual existían eficaces técnicas de burlamiento ${ }^{17}$. La frecuencia con la que estas restricciones eran sorteadas, no impedía que las muchachas pudieran ser conceptuadas por los varones como aliadas objetivas de la moral social en materia sexual, encargadas de ejecutar, en última instancia, la normativa relativa a la prohibición de las relaciones sexuales completas antes del matrimonio. También reténgase aquí el papel que Pérez Díaz asigna al sacerdote en la constatación de este tipo de ambivalencias, como «expresión límite y personificación de esta moral» ${ }^{18}$.

En el momento de iniciar unas relaciones que podían devenir en noviazgo y, más adelante, en matrimonio, el novio se encontraba, por lo general, intensamente integrado en la vida del grupo formado por los jóvenes de su edad; grupo del que la colectividad, a través de la dependencia que creará en él la fascinación ejercida por la amada, intentaba crecientemente apartarle. Al lograrlo, habrá terminado para el muchacho un período, el de mocedad, en el que había desaparecido casi por completo el control materno. Esta situación de independencia habrá servido para estimular aún más si cabe la impaciencia instintual del joven mediante la permanente invitación por parte de la colectividad a que se comportase de forma plenamente activa, incluso hasta cierto

17 Como las recogidas en numerosos pueblos manchegos - Pétrola, Casas Ibáñez, Valdeganga, El Ballestero, Villarobledo, Jorquera, Bogarra, Ossa de Montiel, Nava de Abajo, Vianos...- M. R. CANDEL y M. D. SimarRo, «Prenoviazgo, noviez y boda en la provincia de Albacete», V Jornadas..., pp. 12-29.

18 PÉREZ DÍAZ, op. cit., p. 151 (nota). 
punto desordenada, para que ello le condujese a requerir una vida sexual lo más segura posible, que le liberase de la precariedad e irregularidad $\mathrm{y}$, por supuesto, insatisfacción crónica de la actividad erótica propia de esta fase.

La instrumentación de que la comunidad hacía objeto a las mujeres jóvenes y la plena aceptación por éstas del papel social que se les encomendaba, en orden a arrastrar a los varones a un proceso de seducción-domesticación que les estimulase a entrar sin resistencias en el ámbito familiar, venía favorecida, hay que recordarlo, por el pavor de las mujeres a quedarse solteras - «para vestir santos», como solía decirse-, en una sociedad en la que las llamadas «solteronas» eran objeto de pública conmiseración. Esto conducía a que gran parte de la actividad de las jóvenes, en el plano social, se centrase, hasta no hace mucho, en la búsqueda de un varón con el que casarse, actividad cuyas acciones recibían significativas designaciones epitéticas como «capturar», «cazar», "pescar», etc. Además de la interiorización del ideal del matrimonio como máxima aspiración de la mayoría de jóvenes ${ }^{19}$, para el desarrollo de la estrategia femenina de estimulación-restricción y protección de la propia virginidad, jugaba un papel importante el sistema de sanciones morales de que la colectividad disponía para aquellas mujeres que hubieran protagonizado alteraciones en las normas sobre castidad prenupcial. Por otro lado, también contribuía la convicción que se tenía de que los varones sólo aspiraban, en última instancia, a ver satisfechos sus instintos sexuales y que un exceso de accesibilidad en estos terrenos solía ser catástrofico para la cotización sexo-social de la moza.

En Almadén, el período de noviazgo era objeto de una compartimentación temporal que servía para puntear el proceso que llevaba al novio a profundizar en un complejo de compromisos emocionales, interfamiliares e, incluso, económicos crecientes; complejo que, cuanto más extendido, más difícil hacía su liquidación y la vuelta del mozo al estado de plena soltería. Dotado de la típica mecánica del rito de paso, el noviazgo se ponía en marcha a partir del apartamiento del neófito -el novio- de su ámbito hasta entonces propio -el grupo de mocedad masculina. A medida que se iba aproximando la resolución del tránsito, el momento en el que sería reintegrado a la sociedad con un nuevo estatuto ya plenamente definido - el de hombre casado y con respon-

19 Tal y como quedaba corroborado estadísticamente para una época cercana en M. García Ferrando, Mujer y sociedad rural (Madrid: Cuadernos para el Diálogo, 1977), pp. 115-32. 
sabilidades familiares-, el novio iba también asumiendo la evidencia de que, por decirlo así, había sido atrapado en una tupida red de intereses de todo tipo, que resultaban cada vez más difíciles de contrariar. En último término era toda la comunidad la que presionaba para que el prometido fuera introduciéndose en esta maraña de compromisos y que, aunque se sintiese tentado a ello, no renunciase a sus proyectos de casamiento.

Esta compartimentación del tiempo de pasaje hacia la constitución de una familia de procreación cuenta con numerosos testimonios etnográficos de su extensión en la zona manchega. Así, en Villacañas, por ejemplo, existía una primera fase, que era llamada de esquina; una segunda, de puerta, y una tercera, de entrada ${ }^{20}$. En esta última el futuro esposo era ya integrado en aspectos de la vida doméstica de la novia y de su familia, lo que implicaba la plena aceptación de ésta y la cota máxima de compromisos nupciales. En Almadén, la primera fase era llamada de ventana, en tanto el cortejo se realizaba en las ventanas enrejadas de la casa de la novia, desde cuyo interior la moza se relacionaba con el pretendiente platicando y «haciendo lo que se podía», por utilizar una expresión de mis informantes masculinos, limitado esto a contactos muy menores pero altamente excitantes para los implicados. La siguiente fase era designada como puerta. Ahora, las conversaciones íntimas y los contactos físicos tenían lugar en la puerta de la casa de la novia. Por descontado que las actuaciones eróticas en esta situación eran perfectamente conocidas por los padres de la novia, que consentían en ellas simulando indiferencia, aunque controlando discretamente los excesos, ya que se entendía - o como mínimo así se afirmaba- que «ese no es el lugar más indicado para esas cosas». En efecto, las parejas contaban con momentos suplementarios de intimidad, en apariencia clandestinos pero en realidad tolerados y, aún más, soterradamente promocionados por la colectividad, en que los contactos físicos de las parejas podían ser más estrechos, aunque $-\mathrm{y}$ de esta vigilancia se encargará la novia - se evitara en lo posible que éstos fueran plenos. La tercera fase era llamada como de mesa. El novio era ya invitado a entrar en la casa de la novia y se le incorporaba a determinadas actividades familiares. En cierto modo era ya considerado como un hijo y se le concedía un elevado grado de confianza. Las escaramuzas eróticas se verificaban muy frecuentemente en habitaciones de la casa, lo que también contaba con el solapado beneplácito de los padres. Es más, existía un

20 Cf. M. P. SARABIA, «Boda en un área manchega (Villacañas) y en La Sisla (Mazarambroz)», V Jornadas de Etnologia..., pp. 121-34. 
tácito acuerdo - me contaban- según el cual, el pariente que se aproximara a la pieza en que se encontraban los novios a solas debía hacerlo de la forma menos sigilosa posible, provocando al acercarse el ruido necesario para que los enamorados tuvieran conocimiento de su proximidad.

Esta secuencialización del noviazgo funcionaba a la manera de un deslizamiento hacia la creciente complicación de los jóvenes en compromisos, cada vez más insoslayables. Se trataba de operaciones protocolarizadas destinadas a que resultase crecientemente dificultoso renunciar a los proyectos matrimoniales, especialmente para el novio, el engarce más inseguro del sistema, hacia cuyas actividades y comportamientos la sociedad demostraba una especial preocupación y sobre el que ejercía una presión de influencia más intensa.

\section{Violencia y Ritual EN AlmadÉN}

Esta insistencia en que la fase de mocedad, la prenupcial de los muchachos, desenvocase en su destino deseable, es muy probablemente que se halle tras no pocos aspectos de la práctica festiva. Las fiestas de San Sebastián y de San Antón resultan bastante explícitas en ese sentido, como ocurre con la popularísima excursión al campo del Domingo de Resurrección. Aquí resulta esencial llamar la atención acerca de dos significativas alusiones a la extrema masculinidad. En primer lugar en el papel protagonista que, en una celebración basada en la exaltación de la domesticación como es San Antón, se concedía a los burros, animales cuyo status simbólico siempre había estado vinculado a su fama de bestia permanente en celo. $\mathrm{Y}$, en segundo, en un asunto en el que habremos de detenernos más adelante: el carácter indisimuladamente itifálico del Judas que se destruye el Domingo de Pascua. Hay que destacar que toda la zona manchega está saturada de celebraciones en las que se escenifica la derrota, a manos de la sociedad, de una entidad peligrosa, a la que se hace proceder del exterior para que figure la sedición del orden de la comunidad, con una especial atención formal en que quede subrayado que es en su condición de macho desmadrado donde reside su principal factor de amenaza. Se trata de sujetos rituales del tipo «máscaras fustigadoras» - a la manera de los zamarrones norteños, por ejemplo-, armados de palos, látigos, vejigas o de artilugios que les permiten golpear o, con mucha frecuencia, ensuciar de hollín, harina, serrín o cualquier otra sustancia inconveniente, al público, y en especial a mujeres y niños, con lo que resulta pertinente 
conjeturar una intención expresiva antifemenina y antifamiliar. Es el caso de los morraches de Malpica de Tajo o de Los Navaluchos (en Toledo), del zagarrón de Condemios de Arriba (Guadalajara), del porra de Valdecañas (Cuenca), del zorra de Valverde de los Arroyos (Guadalajara), del perle de Herencia (en Ciudad Real), de los perros de Sana Ana de Pusa (Toledo), etc. ${ }^{21}$. Sin duda, la expresión más elocuente de este tipo de personificaciones de la peligrosidad masculina son las botargas que extienden sus variantes a lo largo y ancho de La Mancha: el del Niño Perdido, agresor con castañuelas en Valdenuño Fernández; con una naranja con la que golpea en la nariz a las muchachas y niños a los que se la ofrece, en Montarrón y en Beleña; el de Albalate de Zorita, la pareja de Majaelrayo, el de la caña con vejiga de Mazuecos, tirando ceniza y pelusa a las chicas en Retiendas, el de Peñalver... (todos de Guadalajara) ${ }^{22}$. Este operador simbólico es identificable también en las figuras demoníacas de las que La Mancha albergaría varios ejemplos valiosos, como los diablos de Almonacid del Marquesado (Cuenca) ${ }^{23}$.

El otro gran aspecto intrigante del ciclo festivo almadenense es el que constituye la presencia de disidencias ritualizadas, que se articulan integradamente en el conjunto de las ceremonias, manteniendo con él una relación de simetría y a la vez de tensión. Es como si todo el sistema estuviera abocado a sostenerse únicamente en base a un crispado diálogo consigo mismo, como si necesitara contradecirse e incluir dentro de sus propios desarrollos sus correspondientes antítesis. Cada rito se desmiente a sí mismo, se contraría y se desautoriza. Cada ceremonial implica su propio anticeremonial, su negación. Debemos reconocer aquí ese principio de contrarritualidad según el cual los ritos, delegados por el conjunto de la dinámica social para actuar vehementemente en nombre de sus principios, exponiéndolos como sobrenaturalmente ins-

21 Estos y otros ejemplos aparecen descritos en Consuelo González CaSArrubios, Fiestas populares en Castilla-La Mancha (Ciudad Real: Comunidades de Castilla-La Mancha, 1985), passim.

22 Cf. J. Caro Baroja, «A caza de botargas», RDTP, XXI (1965), pp. 273-392; J. R. LÓPEZ DE LOS MOZOS, «Las botargas, su simbolismo y cambios de significado. (Hacia una idea de folklorema)», I Jornadas..., pp. 113-33; J. de la Fuente CAMINALS, «Botarga del Niño Perdido en Valdenuño Fernández (Guadalajara)», RDTP, VII (1951), pp. 3523; S. GARCf́A SANZ, «Botargas y enmascarados alcarreños», RDTP, IX (1953), y «La botarga de San Blas en Peñalver», Arriaca, 4 (1983); E. NAvarrete, «La botarga de San Blas en Peñalver (Guadalajara)», RDTP, VII (1951).

23 Cf. J. Caro Baroja, «Los 'diablos' de Almonacid del Marquesado», RDTP, XXI (1965), pp. 40-2; C. GonZÁlez CASARrubios, «Notas sobre los diablos de Almonacid del Marquesado», Narria, 5 (marzo de 1977), pp. 32-5. 
pirados y como incontestables, requieren, por la propia violencia que suelen invertir en su despliegue, dispositivos de compensación que hagan tolerable la presión que ejercen sobre las personas individuales o grupos que son objeto, por así decirlo, de la regulación ritual. Esta mecánica homeostática funciona a partir de la inclusión, dentro de la maquinaria de acción social que son los ritos, de espacios, no menos protocolizados e insertos dentro del propio ejercicio ritual socialmente reconocido, en los que los elementos que son víctimas de la inevitable violencia ritual pueden exponer y hacer exterior su disidencia y su agresividad con respecto a la legislación que las representaciones rituales sirven para imponerles. Se trata, como se ve, de un sencillo ingenio ritual, provisto por la factoría social de representaciones, basado esta vez en un principio de retroalimentación negativa y destinado a hacer tolerables los altos dinteles de tensión que el sistema ritual, auténtico mediador a la hora de establecer el orden en esa especie de guerra civil contenida que es toda forma de vida social ${ }^{24}$, genera de manera constante.

Almadén podría proveernos de un buen ejemplo de ese tipo de recursos contrarrituales mediante los que el sistema ceremonial puede dialogar crispadamente consigo mismo y someter a integración las contradicciones y el descontento que él mismo exuda. Pero cabe subrayar un aspecto de esa negación que el ejercicio ritual formula de sí mismo. Acaso en relación con el hecho de que el colectivo femenino ocupaba un lugar más que privilegiado y prioritario en el mantenimiento y ejecución de los ritos, los pronunciamientos de contrarritualidad ofrecían un innegable énfasis en la intervención de la división sexual, que otorgaba a los varones un lugar destacado en la manifestación ritualizada de las disidencias. Esto lo podíamos constatar ya en el que quizá sería el paradigma perfecto de la autodisidencia asimilada por el lenguaje ritual socialmente homolgado: el Carnaval, cuya eficacia, a la hora de aliviar las cargas y renuncias que la sociedad impone a través de los ritos, ha quedado ampliamente probada en las culturas de orientación católica ${ }^{25}$. En Almadén

24. Este símil de guerra civil es muchas veces adoptado en un sentido exacto y explícito. En relación con la ejecución ritual del Judas, de la que en seguida hablaremos, ahí está la batalla campal, que organizan los vecinos de Membrilla, el Domingo de Resurrección. Cf. J.-M. GAllego JimÉnEZ, «Aspectos sociológicos de la fiesta popular en Membrilla: los grupos festivos», Actas de las IV Jornadas de Etnología de Castilla-La Mancha, Albacete, 1986 (Toledo: Junta de Comunidades de Castilla-La Mancha, 1988).

25 La configuración carnavalera almadense y sus implicaciones estructurales se parecería bastante a la reflejada en J. MARcos ARÉvalo, «Los carnavales en la ciudad de Badajoz, 1900-1936: ¿Reproducción de las estructuras? ¿Antiestructura? ¿Ritual de rebelión del orden social? ¿Naturaleza versus cultura? Notas», Antropología cultural en Extremadura (Mérida: Asamblea de Extremadura, 1990), pp. 278-281. 
tanto las estudiantinas de signo galante como las más mordientes murgas estaban exclusivamente formadas por varones.

Habría más ejemplos. El más elocuente, el de la procesión de San Sebastián. Cuando la comitiva alcanzaba las instalaciones de la mina, en particular el lugar donde se fundía el mercurio (conocido como Bruitrone), los trabajadores dejaban sus puestos de trabajo y salían para ver pasar la imagen. Cuando llegaba a su altura, prorrumpían en improperios y en alusiones a su exhibicionismo y a su ambigüedad sexual. "iDegenerao!", "'Maricón!", "'Tápate, so guarro!", etc., me cuentan que se le gritaba. Un tipo de descalificaciones que no debería sorprender, al menos conociendo la tendencia manchega a concomitar lúbricamente ciertas imágenes santas, como la del veneradísimo Cristo de los Tres Faroles, en Bargas (Toledo), aquel icono al que el imaginero decidió instalarle tres testículos bajo el fajín, con el fin de que el suyo fuera el más cojonudo de la comarca. Todavía más, los empleados de la fundición ya tenían, a la llegada de la procesión, listas unas bolas de papel que, simulando piedras, lanzaban contra la procesión, como para hacer inequívoca la voluntad destructiva y violenta de su actitud. Debe llamarse la atención acerca del hecho de que no estamos hablando de una actuación espontánea o imprevista, sino de una secuencia más de todo el proceso ceremonial, perfectamente esperable y que se repetía como un elemento más de los actos de la liturgia popular del día. Tampoco habría de resultar chocante el que la agresión tumultuosa formara parte del programa de actos de cada Semana Santa. No se olvide que es también en La Mancha donde, cada año, las «turbas», formadas por varones en estado habitualmente etílico, simulan la violencia contra las severas procesiones conquenses.

Todavía más esclarecedora era la práctica contrarritual presente en la vibrante Semana Santa almadenesa. En las noches de procesión, mientras las mujeres se volcaban en el culto y los jóvenes jugaban en El Óvalo, los varones adultos permanecían reunidos en las tabernas hasta la madrugada comiendo chocolate con churros y bebiendo aguardiente. Más sugerente todavía era el uso del juego de bolos manchego. La forma como se practicaba en Almadén implicaba algunas selecciones significativas dentro del repertorio de variables que este deporte tradicional presenta en toda la zona cultural manchega ${ }^{26}$. La opción del terreno se inclinaba por el de pendiente y hacia arriba, en lugar del llano que

26 J. PlazA, «El juego de los bolos en diferentes pueblos de la provincia de Ciudad Real», III Jornadas..., pp. 299-309; J. J. EsPADAS, «Juegos y costumbres populares en la comarca de Infantes y de sus alrededores», IV Jornadas..., pp. 404-10. 
se escoge en otros lugares, de igual modo que se desechaba la modalidad de jugarlos en las afueras del pueblo y se utilizaba cualquier espacio algo empinado disponible en el núcleo urbano. En Almadén sólo juegan a los bolos los hombres y sólo se juega durante la Semana Santa, y, es más, es ésta la actividad diurna que ocupaba la mayor parte del tiempo a los almadenenses adultos a lo largo de esas fechas sacramentales. Significativo debería considerarse el que, mientras la comunidad de las mujeres se hallaba entregada a la evocación ritual de un episodio mítico, cual es el de la muerte en el Monte Calvario de Cristo acompañado por los otros dos crucificados, y sólo en ese mismo momento, los hombres, y sólo los hombres, se dediquen a agredir a tres erecciones en un montículo.

\section{LO MASCULINO Y LO FEMENINO: ESPACIOS, FIGURAS}

Cuando visité Almadén, con el fin de confirmar mis datos de historia oral recogidos entre la comunidad almadenense emigrada a Barcelona, cuidé de hacerlo cerca de las fechas de Semana Santa. En aquella oportunidad pude comprobar cómo, felizmente, se continuaba practicando el juego masculino de los bolos, y también cómo la gente abandonaba en masa el pueblo para irse al campo a comer y a «mantear el Judas» ${ }^{27}$.

Al llegar el momento de salir, de la mano de mis anfitriones, como todo el mundo, hacia las grandes extensiones de encinares para compartir juntos el cordero, pude contemplar, humorísticamente sentado a la puerta de una de las casas que flanqueaban la carretera, un magnífico Judas. Me llamó la atención sobre todo el que hubiera sido acomodado ante una mesa a la que se había servido un vaso de vino, una botella y un plato con frutos secos. Indudablemente, el Judas en cuestión se encontraba haciendo lo que allí llaman la «vaca», expresión con que mis padres - hijos de Almadén-y sus paisanos extrañados aludían al aperitivo que se toma antes de comer y que constituye una práctica de sociabilidd específicamente masculina.

Pero, lo que me sorprendió en extremo fue que aquel monigote vestido con ropas de varón ostentara una mazorca de maíz simulando un considerable falo erecto, que asomaba arrogante de entre la bragueta de su pantalón. La verdad es que no me consta que esta modalidad de

27 Cf. González Casarrubios brinda ejemplos de «manteo» relativos a Yepes, Santa Cruz de la Zarza, Camuñas, Villarrubia de Santiago y otras poblaciones en Fiestas tradicionales toledadanas, Temas toledanos extra 1981, pp. 34-35. 
Judas se dé en la zona y sólo cuento con la referencia de lo que, a propósito de algún caso parecido, cuenta García Sanz localizándolo en la provincia de Guadalajara ${ }^{28}$. Semejante rasgo, que a aquello a lo que llamamos «buen gusto» se le hubiera antojado una descomunal expresión de grosería y ordinariez, me llamó hasta tal punto la atención que pedí detener nuestro vehículo para descender y gastar casi un carrete fotográfico en plasmar tan insólita imagen. Estaba convencido de que aquel Judas venía a ser una manifestación periférica de la representatibilidad del Judas, en la que se plasmaba con extrema transparencia la identificación entre virilidad y peligro antisocial. Pero, en realidad, el fenómeno tenía una dimensión mucho más aparatosa de lo que yo había supuesto al principio y mi carrete invertido en aquella exaltación de la genitalidad masculina pronto devino un gasto completamente inútil. ¡Todos los Judas eran así! Imagínese toda aquella bucólica planicie arbolada llena de familias felices, de mujeres preparando la comida y de niños alborotados, sembrada aquí y allá de múltiples - una por grupo- expresiones de semejante apoteosis de lo obsceno. Por otra parte, no sólo era que todos los Judas eran itifálicos, sino que, además de vestir como lo haría un varón convencional, en muchos casos eran figurados - como el encontrado en primera instancia- haciendo la «vaca», es decir, en una actitud de inspiración muy poco bíblica, pero que en cambio estaba sugiriendo, sin duda alguna, un equivalente entre aquel Judas en estado de excitación sexual permanente y cualquiera de los individuos adultos del sexo masculino, tal y como pueden ser vistos con frecuencia en la calle o en el bar y tal y como pueden ser imaginados en una tradición cultural que nunca ha ocultado la convicción característica de la imaginación machista según la cual todos los hombres son iguales y siempre están pensando en «lo mismo».

Ese podría ser precisamente el sentido de la manipulación cruenta a que la comunidad somete al Judas. La excursión que toda ella, corporativamente, emprende a los encinares que rodean el pueblo funciona como la ocupación integradora y exaltadamente familiar de un espacio exterior, lo que equivale a su domesticación simbólica. Un espacio exterior que es de forma explícita - debe decirse - asimilado a la masculinidad. Me llamó la atención, en ese sentido, que se me informara de que, en aquellos tiempos, era costumbre, al llegar el otoño, que los hombres fueran a cazar «colorines» (jilgueros) a esa zona, prácticamente silvestre, que una comarca volcada en las tareas derivadas de la minería

28 F. Garcfa SANZ, «La quema del Judas en la provincia de Guadalajara», RDTP, IV (1948), pp. 619-25. 
del azogue apenas si atiende. Práctica esencialmente masculina -que recuerda la ritualizada salida al campo de los hombres para cazar perdices por San Blas, en Arcicóllar (Toledo) - en la que las mujeres no podían integrarse, a no ser que estuvieran dispuestas a que se murmurara sobre su honorabilidad - ¿qué podía ir a hacer una mujer a las afueras? Allí, en ese ámbito de dominio masculino, es donde se procede al linchamiento del Judas, cuyos rasgos inequívocamente remiten a la imagen del varón adulto, siempre sexualmente dispuesto, siempre en el bar y, ahora, sometido al despedazamiento tumultuoso por parte de las familias del pueblo, entre cuyos componentes está él mismo, en su aspecto ya fagocitado, resignado ante su domeñamiento y que confirma sus renuncias participando en un rito que significa - sin duda, entre otras cosas- su propia destrucción, alegoría de una socialización culminada que sólo encuentra en la violencia agresora -y para el varón, autopunitiva - un vehículo eficaz para resultar representable ante el pensamiento.

Esa colonización simbólica de que son objeto cada año los territorios, sugeridos como inhóspitos, que se extienden más allá de los límites de la vida urbanizada, tiene lugar justo el domingo de Pascua, el día por excelencia en que la comunidad celebra su triunfo sobre las fuerzas disolventes y antisociales, la más peligrosa de las cuales - a la vez que su requisito más indispensable en lo que tiene de energía para el funcionamiento y la reproducción de la vida social - es la masculinidad no domesticada o díscola que el pelele representa. De hecho, no es casual que, en el momento del manteo familiar, lo primero que se desprenda, por la violencia de que es objeto el monigote, sea su falo postizo, con lo que perceptivamente la ceremonia tiene todo el aspecto de una vérdadera emasculación. Lo que, dicho sea de paso, tampoco sería un rasgo del todo insólito y nunca percatado, como lo demuestra el que Caro Baroja, refiriéndose a la extendida costumbre de instalarle flores en la pretina a los Judas en ciertos lugares para luego arrancárselas, diga de tal geso que es «como si lo castraran» ${ }^{30}$.

Y entre los páramos externos y el calor de lo social..., El Óvalo. No es casual que la tradición ordenara que los jóvenes jugaran a la transgresión ritual en ese terreno mixto, ambiguo, justo señalando el límite entre un espacio y otro, entre lo «crudo» de los encinares y los varones que se escapaban a ellos a capturar pájaros, y lo «cocido» que habitaba los hogares. Era allí el lugar donde los dos mundos, el del caos creador pero peligroso y el cosmos creado y domesticador, debían llevar a cabo

30 Julio Caro Baroja, El Carnaval, (Madrid: Taurus, 1979), p. 141. 
sus negociaciones, justo en el momento mismo en que agoniza el Señor, un joven dios que también vino de fuera y penetrando en la vida organizada encontró su destino letal. El Óvalo, ese territorio intermedio donde los jóvenes juegan a la gallina y al cinto, y donde se enamoran quizá para siempre, es estructuralmente idéntico al Monte Calvario, ese otro terreno intermedio e intermediario, donde Jesús se convierte en Cristo. En este marco de construcciones que remiten, sin solución de continuidad, del rito al mito, del mito al rito y de una trampa a otra trampa, ya no puede extrañar que sean también las noches del Jueves y el Viernes Santo - las de la Celada prototípica que se conmemora año tras año- las indicadas para que en las casas de los novios devenga aún más sólido lo que empezara entre tontos pasatiempos en El Óvalo, en unas vigilias como aquéllas, algunos o muchos años atrás.

Lo que estoy sugiriendo es que en el ciclo festivo almadenense se produce un reflejo vivo de esa guerra civil incruenta y silenciosa que suele siempre constituir la vida social, y que, como también es habitual, esto se traduce en una dinámica de oposiciones entre ritos y contrarritos; es decir, entre ritos en los que los elementos sociales son situados en el lugar que el sistema les asigna y en los términos de obediencia a la norma que se entiende les corresponden, y otros en los que se permite, mediante el juego de la contestación ritualizada e integrada en el imaginario establecido, aliviar el peso de las renuncias socialmente impuestas a los individuos psicofísicos o, como en este caso aparece remarcado, a ciertos grupos de edad y de sexo. Estos grupos de edad y de sexo, a los que el sistema parece agraviar especialmente y a los que el sistema permite una contestación controlada, parecen ser los jóvenes varones.

A su vez, eso debería ser considerado como el resultante previsible de otros factores significativos presentes en la vida en comunidad en Almadén. Por ejemplo, los fuertes rasgos de eso que los antropólogos culturalistas americanos denominan matrifocalidad, o matriarcado doméstico, que se detectan en la distribución de roles de poder en la esfera doméstica o las ideas y protocolos asociados a una concepción trágica de la condición masculina, como consecuencia de una forma de renuncia disconforme, derivada del expermientar como un auténtico proceso de domesticación el tránsito de la familia de procreación a la de orientación; una circunstancia cultural que debería ser puesta en relación con la forma varonil de instituir un sistema de representación que incluiría aquel escoramiento lúgubreagonístico-nupcial de ciertas prácticas sociales propias de la Semana Santa, al que acabo de referirme. Debe decirse que la naturaleza matrifocal de las relaciones de poder entre los sexos, en familias de clase baja, ha sido una 
cuestión cultivada en trabajos de etnología psicológica ibérica como los de Gilmore y Gilmore acerca de la relación entre «machismo» y sentimientos de inferioridad masculina ante un imaginario despotismo ejercido entre los varones de clase baja andaluza por esposas, madres y suegras ${ }^{31}$, en un cuadro que yo mismo pude verificar para el caso de las familias almadenenses de la emigración con las que trabajé ${ }^{32}$.

Es importante hacer notar que el paisaje tradicional estaba saturado de síntomas culturales que a según qué exegetas del siglo pasado les hubieran permitido sentirse en el verdadero paraíso de los survivals que probarían un pasado matriarcal. Un conjunto de mitos, romances y leyendas harían practicable la gimnasia especulativa sobre presuntos pretéritos ginecocráticos ${ }^{33}$. Un número destacado de fiestas en vigor se situarían en esa misma tesitura interpretativa, en una región cultural sobreabundante en fiestas candelarias o aguedianas.

Esta forma de imaginar el detentamiento maternal del poder sociohogareño tiene manifestaciones bien elocuentes. En la casi totalidad de juegos tradicionales infantiles o juveniles -incluidos aquéllos que practicaban los mozos y mozas por Semana Santa en El Óvalo- existe un personaje que desempeña el papel de director, que es el que todo el mundo pretende. Ese perrsonaje recibe indistintamente el nombre de capitán o -con mayor frecuencia- el de madre. En el lado opuesto del sistema, el personaje que recibe la peor parte es llamado burro, un animal en cuyo valor simbólico asociado a la hipergenitalidad ingenua ya me he detenido. Existen infinidad de juegos basados en la figura predominante de la madre ${ }^{34}$; tampoco resulta difícil encontrarla en al-

3 D. D. Gilmore y M. M. Gilmore, «Sobre machos y matriarcados. El mito machista de Andalucía», Ethnica, 14 (1970), pp. 149-59.

32 M. Delgado, "Cuadro de matrifocalidad en un grupo de familias manchegas emigradas a Barcelona», II Jornadas..., pp. 347-56.

33 Cf. E. Aboy y M. A. Delgado, «Posibles vestigios de matriarcado en cuentos, romances y leyendas de Castilla-La Mancha», II Jornadas..., pp. 489-509; y «Un cuento popular en Castilla-La Mancha: Blancaflor, ideología y praxis», V Jornadas..., pp. 14354.

34 A. B. Tallés Cristóbal, «Algunas de las fórmulas que preceden a los juegos infantiles de La Jara (Toledo)», II Jornadas..., pp. 241-7, y «Tres juegos infantiles en Albacete», Narria, 27 (septiembre de 1982), pp. 23-4; A.-A. Pozuelo ReinA, «Catálogo de juegos infantiles en extinción. Ciudad Real, 1.a y 2.` partes», II Jornadas..., pp. 24958, y «Catálogo de juegos infantiles en extinción. Ciudad Real, 3." parte», III Jornadas..., pp. 121-9; F. J. LÓPEZ FERnÁNDEZ y M. FernándeZ Rodrf́gueZ, «Algunos juegos infantiles de Fuencaliente (Ciudad Real)», ibidem, pp. 469-87; J. J. EsPADAS, op. cit., y "Los 'dondines' y 'plones' en Ciudad Real. Sobre algunas fórmulas, normas y reglas que preceden a los juegos infantiles», V Jornadas..., pp. 190-5. 
gunas fiestas tradicionales castellano-manchegas como la Madre Cochina que preside la Fiesta de la Vaca en San Pablo de los Montes, Toledo ${ }^{35}$. Es destacable, en ese mismo sentido, la extensión en la comarca de prácticas de transformismo ritual, como parte de escenificaciones del triunfo de las potencias socialmente benéficas y positivas - dramatizadas por personajes rituales travestidos - frente a las amenazas disolutorias y sus encarnaciones ceremoniales - personajes obedientes al modelo «botarga». Entre otros casos, merece la pena aludir al de los danzantes de la Fiesta del Cristo de la Viga, en el pueblo toledano de Villacañas ${ }^{36}$, encabezados por el Madriscal, hermano mayor de la cofradía correspondiente, cuya designación viene a ser como una divertida síntesis de las categorías intercambiables «madre» y «capitán» de los juegos infantiles. Otro ejemplo ilustrativo sería el de la Mariscala de la fiesta de Danzantes y Pecados de Camuñas ${ }^{37}$.

La impregnación feminizante de las mediaciones con lo santo y lo sobrenatural trascendía con mucho la esfera propiamente eclesial para extenderse a la magia privada o a las prácticas curativas, vagamente emparentadas con la piedad católica y con «la brujería», tal y como varios trabajos han constatado en la zona, tanto históricamente como en la actualidad ${ }^{38}$, con casos tan estremecedores y cercanos como el de la niña poseída y muerta en exorcismo en la manchega Almansa en septiembre de 1990. A hacer nota también la detección, en la línea de demonización del catolicismo, de una presencia abundante de narraciones y leyendas que presentaban en relación de complicidad a las prácticas de hechicería y el clero rural ${ }^{39}$.

35 Cf. S. Criado y R. Villa, «La fiesta de la vaca en San Pablo de Los Montes (Toledo)», IV Jornadas..., pp. 371-84.

36 Cf. T. Álvarez y J. A. Fernández, «Los danzantes y el Cristo de la Viga de Villacañas (Toledo)», IV Jornadas..., pp. 485-502.

37 P. Yugo, Danzantes y pecados de Camuñas, Temas toledanos, 5 (Toledo: Diputación Provincial de Toledo, 1985).

38 Cf. A. J. Moreno y M. P. Martín-Pozuelo, «La mujer daimeleña»: brujería y ocultismo», en III Jornadas..., pp. 219-25; P. J. LAVADO, «La santera y su entorno; la tía Sandalia, de Villacañas», IV Jornadas..., pp. 525-40; P. MARTín, «Curanderismo en Pedroñeras, Cuenca», V Jornadas..., pp. 45-9; J. BLÁZQUEZ, Hechicería y superstición en Castilla-La Mancha (Toledo: Junta de Comunidades de Castilla-La Mancha, 1985), passim; J. Caro Baroja, «Doña Antonia de Acosta Mexía. Perfil de una hechicera del siglo Xvil», RDTP, XVII (1961), pp. 39-65.

39 Cf. «El clero supersticioso», en BLÁzQuEZ, op. cit., 67-79. 


\section{LA REVANCHA DEL JUDAS}

Lo que ocurrió en Almadén en mayo de 1931 no fue demasiado distinto de lo que había ocurrido en otros pueblos y ciudades del país, ni de lo que ocurriría más adelante. Allí, las consecuencias anticlericales del alzamiento militar de julio de 1936 no pudieron incluir la destrucción iconoclasta porque hacía cinco años que no había nada que derruir ni incendiar. Debe aclararse que nos hallamos en una zona de arraigada tradición socialista y donde la presencia anarcosindicalista era mínima, pero donde el republicanismo radical sí había gozado en su día de un ascendente popular importante. Al poco de proclamarse la República, la destrucción de templos, así como de imágenes y objetos de culto, fue general. La animosidad anticlerical ya estaba abundantemente certificada en los carnavales de los años 30 y Almadén compartía con toda la zona cultural en que se incluía una tendencia al abandono de las prácticas piadosas como el que hiciera aumentar a un 33 por 100 el número de daimeños que no recibieron la extremaunción a finales de la década de $1920{ }^{40}$. Se ha de recuperar aquí la cuestión de las debilidades antropofágicas del anticlericalismo contemporáneo español. En La Mancha, uno de los postres más típicos son esas gachuelas fritas y en leche que se llaman «orejas de fraile». Un dato a subrayar: al igual que ocurría con el juego de los bolos manchegos o con las fiestas juveniles en El Óvalo, las orejas de fraile eran un dulce que se comía preferentemente durante la Semana Santa. La tradición satírica basada en la condición lujuriosa del clero también encuentra en la comarca ilustrativas muestras. De Miguelturra, Ciudad Real, son estas coplas:

El cura de Las Casas
está con pena,
porque no le crece
la berenjena
Estando el cura en su celda,
remendando una alpargata,
de vez en cuando decía:
«iSi cayera una beata!»
Estando un cura en su celda
remendando calzoncillos,
de vez en cuando decía:
« Vaya astil para un martillo!»

40 A. A. Losada Azorf́n, «La religiosidad en Hellín. Estudio a través de los libros parroquiales», IV Jornadas..., p. 475. 
El caso es que todo aquello que había constituido centro de la vida religiosa de Almadén fue sistemáticamente destruido en aquellos días posteriores a la proclamación de la República. Todo el complejo simbólico sagrado en torno al que giraba la vida social almadenense se quiso ver arrasado. Las iglesias de las que hemos hablado fueron saqueadas por la multitudd: San Juan, de Jesús, San Sebastián, la capilla de la Virgen de la Mina, la ermita de la Virgen del Castillo... Los iconos que presidían las liturgias y las procesiones, ante los que muchos de sus enemigos de ahora recibieron el bautismo o se casaron, fueron sacados violentamente de los templos a la calle. Allí, una muchedumbre formada, según todos los testimonios, preferentemente por varones jóvenes los arrastró con cuerdas atadas al cuello y, por la Calle Mayor, el escenario de los desfiles religiosos pero también de los contactos entre jóvenes de distinto sexo, acabó conduciéndolos hasta el escenario de los juegos de falsa apariencia inocente que se celebraban por Jueves y Viernes Santo: El Óvalo, el espacio en que los jóvenes empezaron a sentir sus efectos, aquello que Brenan llamó «la maldición del sexo», el inicio del predestinado proceso de malogramiento de su hasta entonces exaltada virilidad. Allí, ninguna de aquellas imágenes fue incenciada, como ordenaba la difundida costumbre del movimiento iconoclasta español. Lo que se hizo con ellas no podía ser más elocuente y cargado de significado. Se las despedazó tumultuosamente, con auténtica rabia, como si haciéndolo se ejecutara un ajuste de cuentas largo tiempo esperado. Aquella violencia no era nueva, ni en su tono ni en su forma, porque era idéntica a la que cada Domingo de Resurrección se ensañaba con el Judas. En cierta forma, no era sino el maltratado Judas el que aplicaba una singular forma de ley del talión, y lo hacía reproduciendo simétricamente la agresión de que había sido durante acaso siglos objeto. Era el momento de su revancha.

La enseñanza que la experiencia de violencia iconoclasta almadenense, hace más de cincuenta años, nos brinda es variada. Por una parte, nos muestra cómo los compartamientos contrarritualistas, previstos para atenuar la fragilidad de un sistema, continuamente amenazado por quienes se consideran sus víctimas, pueden escapar de control y destruir la precaria situación sociorrelacional que contribuían artificialmente a mantener. Sirve también para poner de manifiesto cómo la ruptura que se expresaba en el exterior por la violencia iconoclasta tenía que haber sido precedida por otra ruptura, que ya se había desencadenado en el dominio subjetivo. La iracundia contra las imágenes rituales no era, en ese sentido, más que la sublimación de lo no-dicho. La formalización bien precisa de los gestos de violencia contra templos y objetos cultuales estaba, 
por otra parte, basada en un imaginario icónico-gestual disponible en la cultura que - a pesar de las desideraciones transformadoras que se explicitaban invocando la presencia redentora del Mundo Modernoera mimado por los violentos. Los revoltosos que se levantaron contra los símbolos sagrados para aniquilarlos estaban poniendo en marcha con su acción asociaciones metafóricas, inferencias causales, construcciones imaginativas, etc., que ya estaban dadas en su universo simbólico y que se utilizaron actuativamente: en la aspiración anticipadora pero sin perfiles claros de otra forma de organizar el mundo, los iconoclastas no pudieron dejar de emplear los mismos mecanismos de representación que pretendían destruir. Por último, nos advierte, a un nivel más concreto, de la insuficiencia de las explicaciones provistas a propósito del anticlericalismo español. Pocas parcelas de la vida religiosa de nuestro país aparecen tan oscuramente tratadas y con tan desmesurada y esterilizante prudencia. Sin discutir las concomitancias político-institucionales y económicas de la lógica del combate anticlerical contemporáneo en España, debe empezar a reconocerse la incidencia de otros factores.

No se trata todavía de aventurar ninguna hipótesis definitiva, ni de precipitar especulaciones explicativas que recompongan el orden lógico en que los comportamientos sacrofóbicos resulten comprensibles. Se trata, por ahora, de reconocer que el estatuto simbólico de la cultura, tal y como se organizaba en Almadén durante la década de los 30 al menos, asignaba a la Iglesia, al clero y a la religión practicada, aparecía directamente complicado con la imaginaria distribución del poder entre los sexos y con el papel que jugaban estratégicamente sus componentes y objetos en procesos cuya interiorización individual se podía pronosticar en extremo frágil: la socialización sexual de los niños y los adolescentes y la incorporación y la lealtad de los varones respecto del sistema familiar. La manía antirreligiosa y la violencia iconoclasta se dirigían contra todo lo que el catolicismo real sacramentaba y la religión y la Iglesia figuraban en el orden de las representaciones. Sin pretender ni remotamente que sea ésa la única parcela de lo real focalizada y capaz de proveer de significación las actuaciones sacrofóbicas, aquí se ha llamado la atención acerca de que uno de los segmentos al que lo santo agredido remitía recurrentemente era el de lo que se entendía eran los hombres y eran las mujeres y las formas simbólicas de que se valía la cultura para construir institucionalmente sus diferencias.

Manuel Delgado Ruiz

Universitat de Barcelona 
Las actuaciones de violencia iconoclasta que ha conocido España en fases recientes de su historia no han sido clarificadas en todos sus determinantes culturales. La interpretación que aquí se hace de las relaciones entre sistema ritual, sacrofobia y conflictos de género en Almadén, un pueblo minero de Castilla-La Mancha, sirve para proponer una aproximación a esos factores que, procedentes del campo extrapolítico, pueden detectarse contribuyendo a la formación de los aspectos inconscientes de la ideología anticlerical española contemporánea.

The instances of iconoclastic violence which Spain has suffered in recent phases of its history have not been explained in all of their cultural determinants. An interpretation is offered here of the relations between ritual system, sacrophobia and conflicts by reason of sex in Almadén, a mining village in Castilla-La Mancha, that serves to put forward an approach to those factors which, arising from an extrapolitical field, may seem to contribute to the forming of unconscious aspects of the Spanish contemporary anticlerical ideology. 


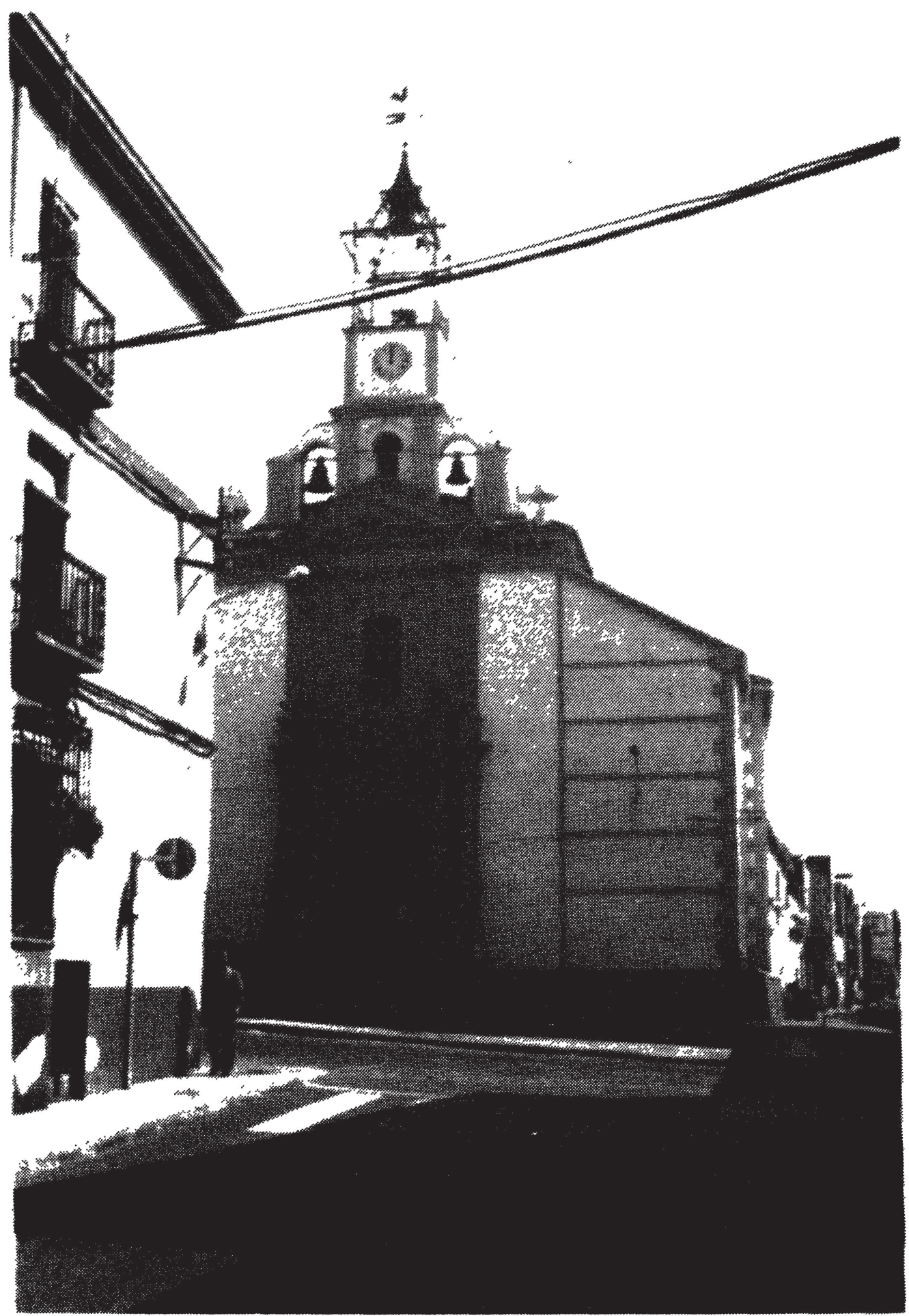

Fig. 1.-Iglesia de San Pedro, la principal de Almadén. Como la de San Sebastián y todas las demás, fue asaltada y destruida en 1931. 


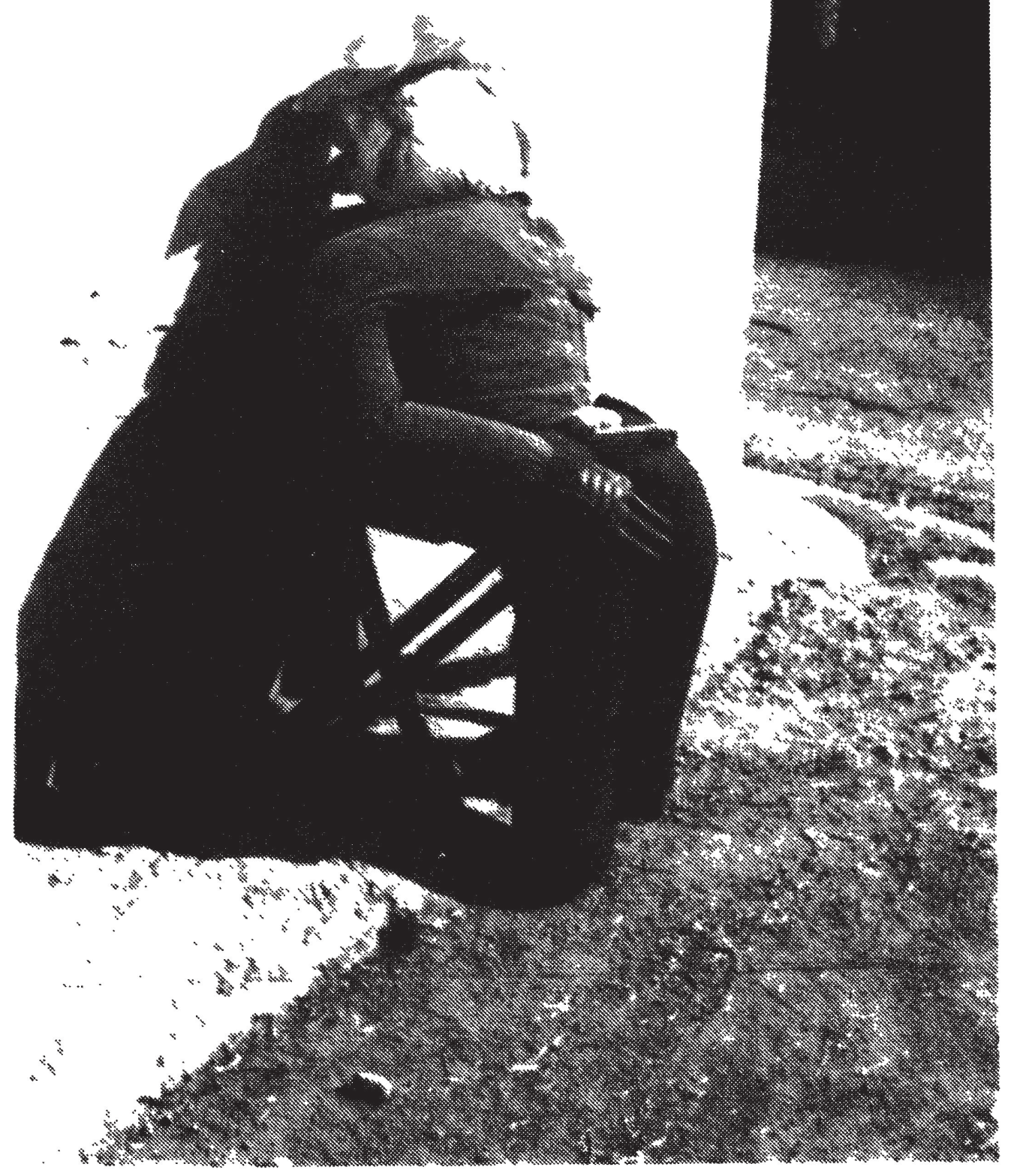

Fig. 2.-Judas itifálico expuesto a la entrada de una casa, en la mañana del Domingo de Resurrección. 


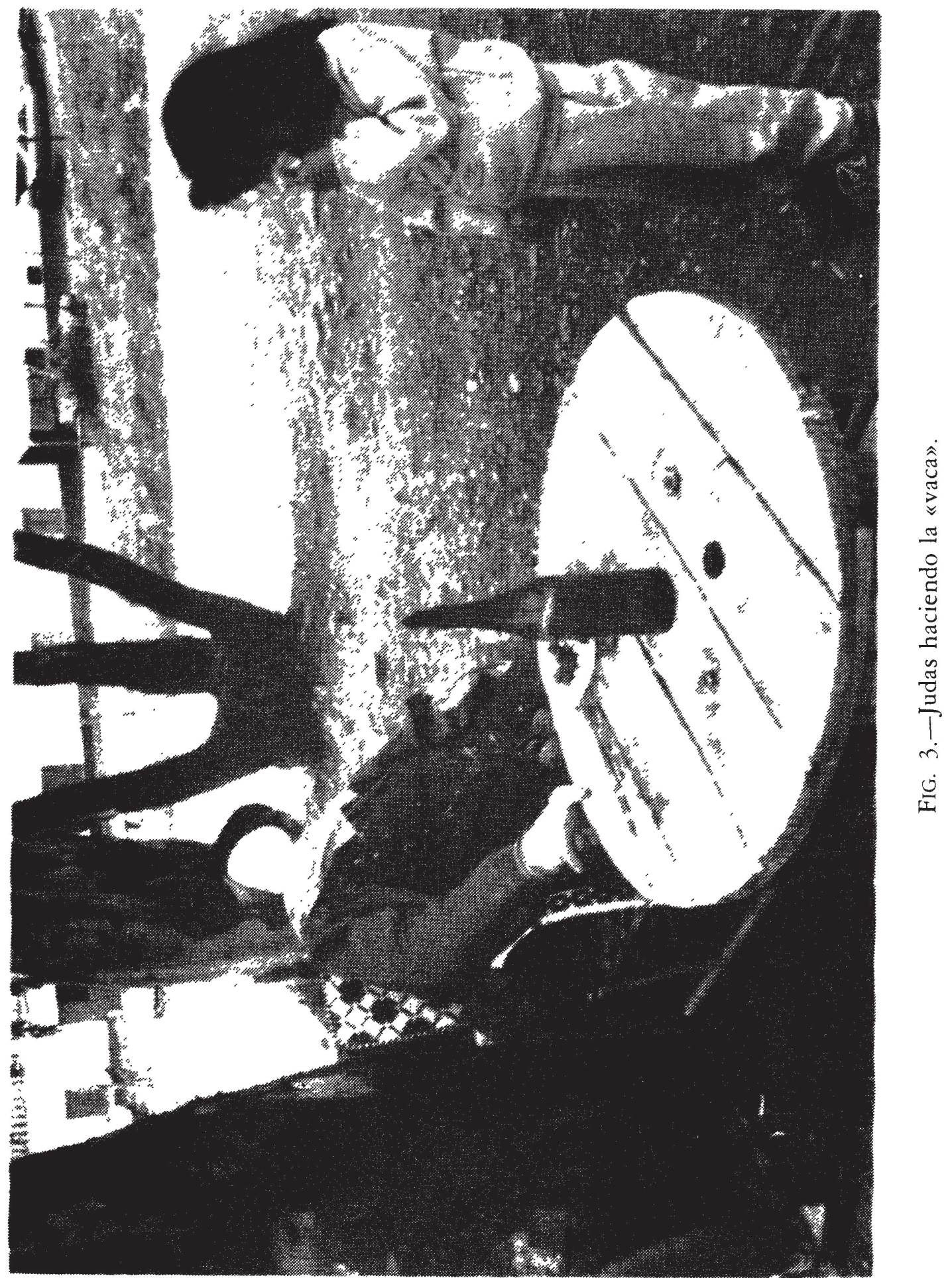




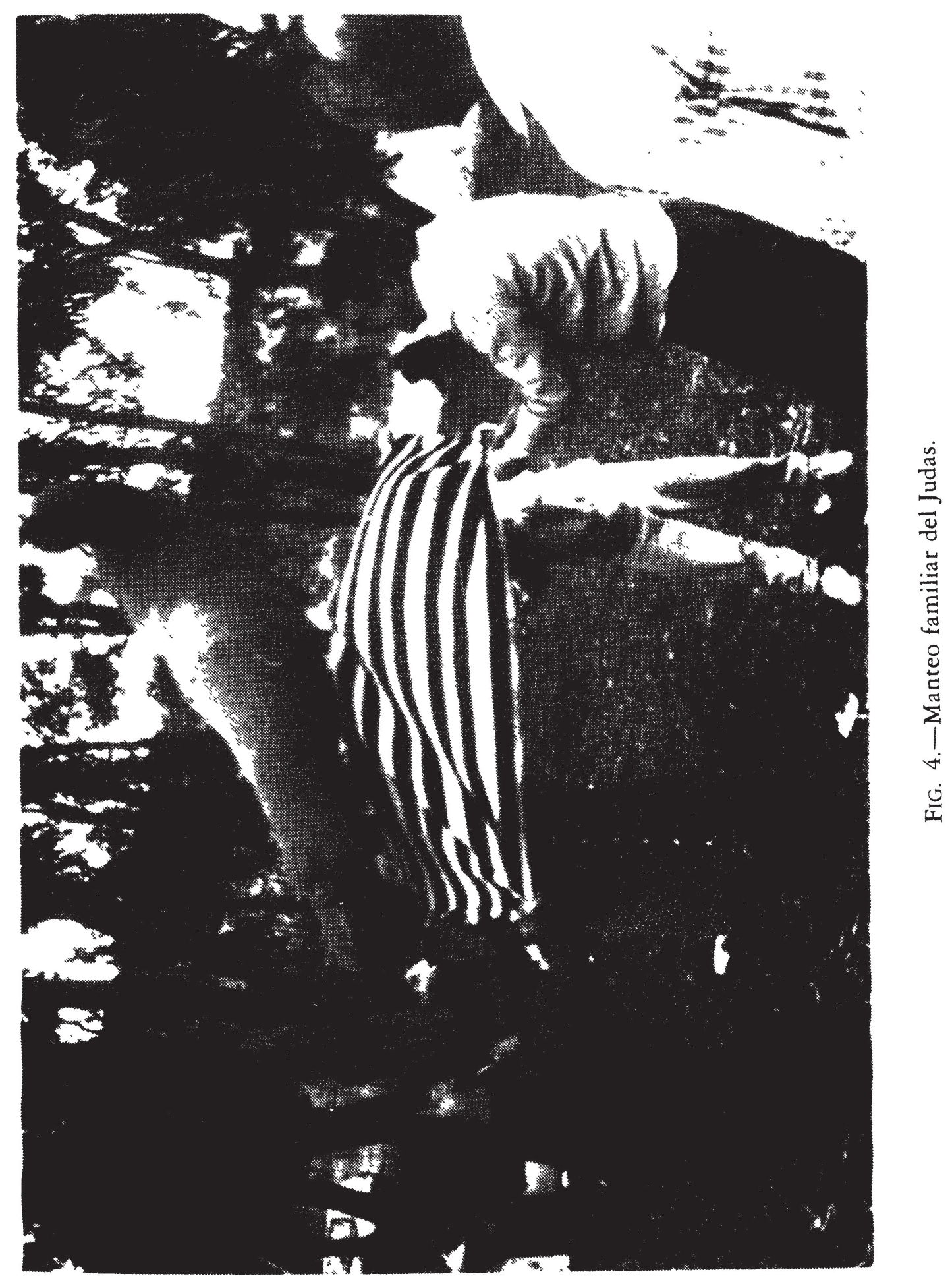

